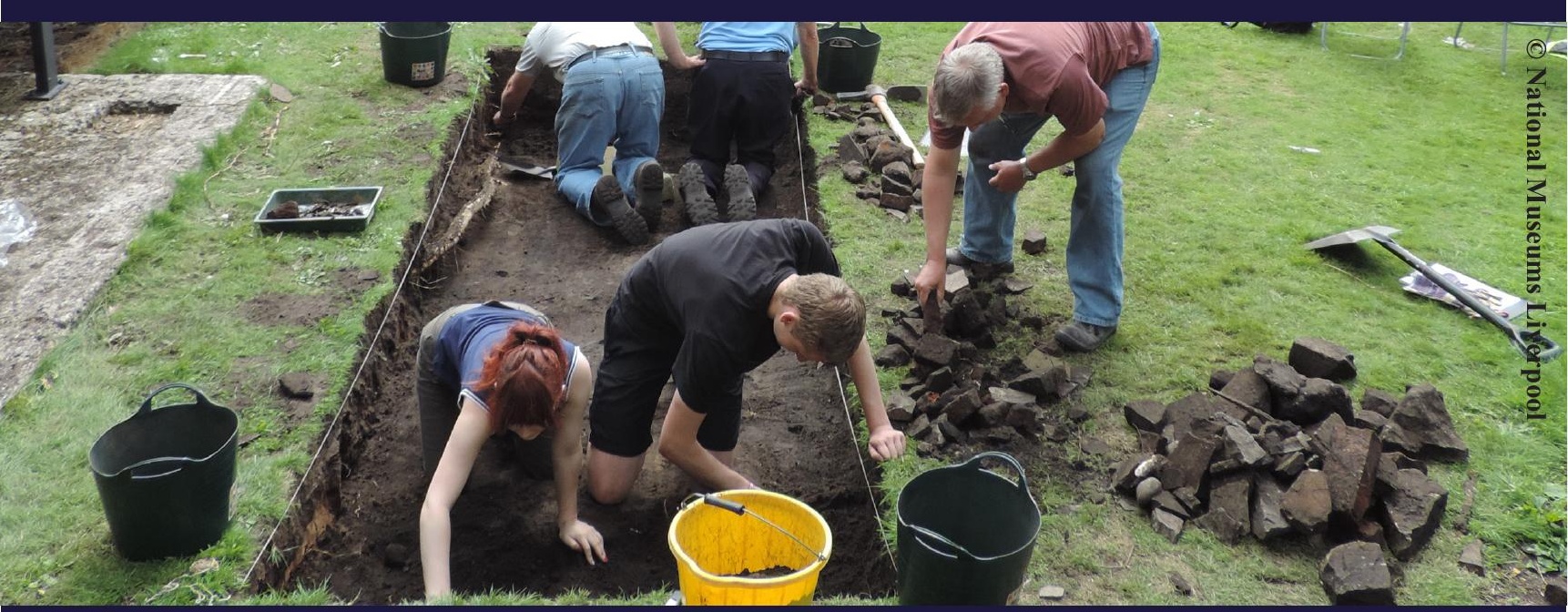

\title{
Editors:
}

Kerry Massheder-Rigby \& Dominic Walker

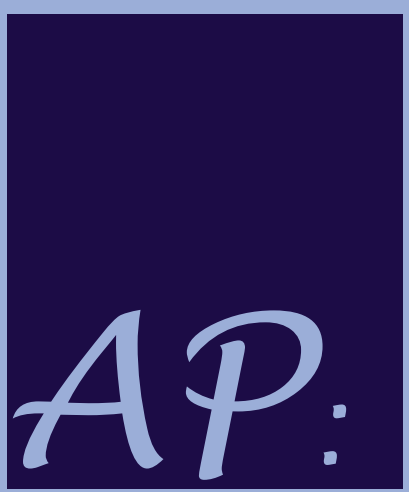

www.arqueologiapublica.es

Ontine Journat in Public Archaeology

Emerging Approaches

to Public Archaeology 


\title{
INTRODUCTION
}

\section{Emerging approaches to public archaeology}

\author{
Kerry MASSHEDER-RIGBY \\ University of Liverpool \\ Dominic WALKER \\ University of Cambridge
}

The papers in this special volume originated in two separate sessions of the 2012 Theoretical Archaeology Group conference held at the University of Liverpool ('Decentering the discipline: archaeology and extra-archaeological communities' and 'New approaches to archaeological outreach, engagement and ownership'). Both recognised the momentum that the study and practice of public archaeology has gained in recent years, an observation supported by the fact that the lecture theatres were filled to capacity during the sessions. They offered an exploration of new ways of approaching some of the multitude of challenges posed towards public archaeologists, especially informed by the state of public archaeology in the United Kingdom, but also informed by and responding to broader debates.

Questions of ownership, authority and benefit emerged as primary concerns. These issues have seemingly produced greater impacts in countries with Indigenous communities, but are being increasingly explored in other countries (Beck and Somerville 2005; Colwell-Chanthaphonh and Ferguson 2008; Dalglish 2013; Nicholas et al. 2011; Okamura and Matsuda 2011; Waterton and Smith 2009). This has been aided by the rise of areas of study such as archaeologies of the contemporary past (e.g. Buchli and Lucas 2001; Graves-Brown et al. 2013; Harrison and Schofield 2010; Orser 2010; Schofield 2014); ethnographies of archaeology (e.g. Edgeworth 2006; Mortensen and Hollowell 2009); digital archaeology and museology (Kansa et al. 2011; Lake 2013; Parry 2010); and wider theoretical developments in museum 
and heritage studies (e.g. Marstine 2011; Waterton and Watson 2013). The notion of decentering was particularly debated in one of the sessions. This was forwarded as a concept that encapsulates many of the efforts of public archaeologists working under various labels (e.g. 'community', 'Indigenous'). It refers to the centering of previously marginal concerns, knowledges and perspectives held by various communities in addition to the more equitable distribution of benefits that accrue from archaeological work (Conkey 2005; Lyons et al. 2010; Silliman 2008; Wylie 2003, 2008).

The collection of five papers here offers a 'snapshot' of some of these complex and emergent discussions. They explore the epistemological and ethical challenges of engaging with extraarchaeological expertise; the authority of archaeologists and the archaeological discipline; disciplinary identity; the potentials and pitfalls of digital work; and, perhaps more fundamentally, the benefits and relevance of archaeology beyond the discipline itself.

Firstly, Donna Yates, explores the issues that arise through disciplinary labeling, informed by her own experience of transitioning from working in 'archaeology' to working in 'criminology'. Secondly, Paul Belford assesses theories of community archaeology by identifying concerns about the sustainability of partnerships between non-professional and professional participants. This is particularly informed by an ongoing public heritage project in Telford. Thirdly, Torgrim Sneve Guttormsen examines the dynamics of heritage production at Haugesund, a region believed to be the homeland of the Viking hero Harald Fairhair, the first king of Norway. The paper emphasises how a popular and commercial past enters into public debates and conflicts, and questions the role 'experts' play in local communities. Kerry Massheder-Rigby's paper questions whether there can be an informative research relationship between archaeology and oral history, particularly when studying late nineteenth and early twentieth century working-class housing. Finally, Dominic Walker surveys public archaeologists' varied uses of social media, highlighting three major factors that prevent the realisation of the more laudable aims of public archaeologists working online: inequities in internet access, the transference of pre-existing authority to online spaces, and the inequitable accrual of resources. 
Throughout these papers, there is a sense that recent debates in public archaeology are not geared towards establishing archaeologists as silent experts with little or no authority. Instead, they are intended to establish other, perhaps 'extra-disciplinary', communities as equal participants or collaborators, expanding disciplinary boundaries and what it means to be an 'archaeologist' (Nicholas 2010; Silliman 2008). In many respects, attempts to decentre authority and practice can be considered a form of activism by taking a stand against the pernicious impacts of archaeology (Stottman 2010). This is opposed to the kind of public archaeology characterised by Dawdy (2009) as 'public-relations archaeology', wherein 'public engagement' and other methods are used in an attempt to prevent controversy and retain public support, but which ultimately bolster the authority of the discipline. Instead public archaeology demands hard work and a higher degree of socio-political, ethical and epistemological awareness to aid a shift towards a more effectively democratic and more broadly beneficial discipline. The papers included in this volume attempt to demonstrate such a shift.

\section{Acknowledgements}

Many thanks go to Cara Jones and Phil Richardson who coorganised the 'New approaches to archaeological outreach, engagement and ownership' session, to Sarah May for her insights, and to all the presenters who spoke in the two TAG sessions.

\section{References}

Beck, W. and Somerville, M. 2005. Conversations between disciplines: Historical archaeology and oral history at Yarrawarra. World Archaeology 37(3), 468-483.

Buchli, V. and Lucas, G. (eds). 2001. Archaeologies of the Contemporary Past. London, Routledge.

Colwell-Chanthaphonh, C. and Ferguson, T.J. (eds). 2008. Collaboration in Archaeological Practice: Engaging Descendant Communities. Lanham, AltaMira Press. 
4 - Kerry MASSHEDER-RIGBY and Dominic WALKER - Introduction

Conkey, M.W. 2005. Dwelling at the margins, action at the intersection? Feminist and Indigenous archaeologies. Archaeologies 1(1), 9-59.

Dalglish, C. (ed.). 2013. Archaeology, the Public and the Recent Past. Woodbridge, Boydell Press.

Dawdy, S.L. 2009. Millennial archaeology. Locating the discipline in the age of insecurity. World Archaeology. 16(2), 131-142.

Edgeworth, M. (ed.). 2006. Ethnographies of Archaeological Practice. Lanham: AltaMira.

Graves-Brown, P., Harrison, R. and Piccini, A. (eds). 2013. The Oxford Handbook of the Archaeology of the Contemporary World. Oxford, Oxford University Press.

Harrison, R. and Schofield, J. (eds). 2010. After Modernity: Archaeological Approaches to the Contemporary Past. Oxford, Oxford University Press.

Kansa, E.C., Kansa, S.W. and Watrall, E. (eds). 2011. Archaeology 2.0: New Approaches to Communication and Collaboration. Los Angeles, Cotsen Institute of Archaeology.

Lake, M. 2012. Open archaeology. World Archaeology 44(4), 47178.

Lyons, N., Dawson, P., Walls, M., Uluadluak, D., Angalik, L., Kalluak, M., Kigusiutuak, P., Kiniksi, L., Karetak, J. and Suluk, L. 2010. Person, place, memory, Tthing: How Inuit Elders are informing archaeological practice in the Canadian North. Canadian Journal of Archaeology 34, 1-31

Marstine, J. (ed.). 2011. Routledge Companion to Museum Ethics. Abingdon, Routledge.

Mortensen, L. and Hollowell, J. (eds). 2009. Ethnographies and Archaeologies: Iterations of the Past. Gainesville, University of Florida Press.

Nicholas, G.P. (ed.). 2010. Being and Becoming Indigenous Archaeologists. Walnut Creek, Left Coast Press. 
Nicholas, G.P., Roberts, A., Schaepe, D.M., Watkins, J., Leader-Elliot, L. and Rowley, S. 2011. A consideration of theory, principles and practice in collaborative archaeology. Archaeological Review from Cambridge 26(2), 11-30.

Okamura, K. and Matsuda, A. (eds). 2011. New Perspectives in Global Public Archaeology. Dordrecht, Springer.

Orser, C.E. 2010. Twenty-first-century historical archaeology. Journal of Archaeological Research 18, 111-150.

Parry, R. (ed.). 2010. Museums in a Digital World. Abingdon, Routledge.

Schofield, J. (ed.). 2014. Who Needs Experts? Counter-Mapping Cultural Heritage. Farnham, Ashgate.

Silliman, S.W. 2008. Writing new archaeological narratives: Indigenous North America. In Rizvi, U. and Lydon, J. (eds), Handbook of Postcolonial Archaeology. Walnut Creek: Left Coast Press, 145-164.

Stottman, M.J. (ed.). 2010. Archaeologists as Activists: Can Archaeologists Change the World? Tuscaloosa, University of Alabama Press.

Waterton, E. and Smith, L. 2009. Heritage, Communities and Archaeology. London, Duckworth.

Waterton, E. and Watson, S. (eds). 2013. Heritage and Community Engagement: Collaboration or Contestation? Abingdon, Routledge.

Wylie, A. 2003. Why standpoint matters. In Figueroa, R. and Harding, S. (eds), Science and Other Cultures: Issues in Philosophies of Science and Technology. London, Routledge, 26-48.

Wylie, A. 2008. Legacies of collaboration: Transformative criticism in archaeology. Paper presented at the American Anthropological Association conference, San Francisco, 21 November 2008. 


\section{AP: Ontine Journal in Public Archaeology}

\section{Editors:}

Jaime Almansa Sánchez

Elena Papagiannopoulou

Assistant Editors:

Dominic Walker

Amanda Erickson Harvey

Kaitlyn T. Goss

Reviews Editor:

Alexandra Ion

Assistant Production Editor:

Alejandra Galmés Alba

Edited by:

JAS Arqueología S.L.U.

Website: www.jasarqueologia.es

Email: jasarqueologia@gmail.com

Address: Plaza de Mondariz, 6, 28029 - Madrid (Spain)

--

Cover Image: Rainford 155 working shot (National Museums Liverpool)

Copyright () 2014 JAS Arqueología S.L.U. (edition) \& Authors (content)

ISSN: $2171-6315$

Quotation:

Massheder-Rigby, K. \& Walker, D. 2014. Introduction: Emerging approaches to public archaeology. AP Journal SV 1, 1-5.

AP Journal is a peer-reviewed journal devoted exclusively to Public Archaeology. It is freely distributed online on the Website:

www.arqueologiapublica.es

You can also follow us on:

Blogger:

Z http://arqueologiapublica.blogspot.com/

Twitter:

http://twitter.com/APjournal

Facebook:

1 http://www.facebook.com/APJournal 